\title{
26
}

\section{The shifting place of Ngai Tahu rock art}

\author{
Gerard O'Regan \\ Ngai Tahu Maori Rock Art Trust, 27 Strathallan Street, P0 Box 983, Timaru, New Zealand \\ gerard.oregan@xtra.co.nz
}

\section{Introduction}

As Ngai Tahu's pre-eminent archaeologist, Atholl Anderson's contribution to southern Maori archaeology and historical research is well recognised, but less widely acknowledged is his involvement in the shaping of modern heritage-management directions within his tribe. During the early 1990s, Anderson was a founding member of Komiti Tuku Iho, the tribe's heritage committee, that among other things, articulated a tribal policy statement on human remains. This has resulted in the return to tribal care of all the relevant skeletal remains from museums within New Zealand (see O'Regan 2006). He was a primary author of Ngai Tahu's policy on the management of archaeological and rock-art sites, now regularly referred to in tribal resource-management plans and land-development consent processes, and with Brian Allingham, he founded the South Island Maori Rock Art Project, a survey project that was the genesis of the current Ngai Tahu Maori Rock Art Trust. This paper is an acknowledgement of Anderson's contribution to shaping Ngai Tahu's modern management of its heritage sites and their increasing relevance to expressions of tribal identity.

Wahi tapu are 'places held in reverence according to tribal custom and history' (Tau et al. 1992:s4:25). Associated with earlier generations, the most important among them are urupa (burials), as 'The dead are a link to the past and to the land' (Tau et al. 1992:s4:25). Today the term wahi tapu is attached to many places of historical and cultural significance to Maori (Mead 2003:69), including some places also categorised as archaeological and rock-art sites (see New Zealand Historic Places Trust 2004:45; Kai Tahu ki Otago 2005:63). The Historic Places Act (HPA) 1993 defines wahi tapu as a 'place sacred to Maori in the traditional, spiritual, religious, ritual, or mythological sense' (HPA 1993:s2) and makes provision for their registration. It defines archaeological sites as 'any place in New Zealand that - (a) either - (i) was associated with human activity that occurred before $1900 ; \ldots$ and (b) is or may be able through investigation by archaeological methods to provide evidence relating to the history of New Zealand' (HPA 1993:s2), and imposes restrictions on their uncontrolled modification. While a place may have both wahi tapu and archaeological values, each set of values is currently classed and protected separately under legislation. 
There is provision in the HPA for Maori to be consulted on cultural values about proposed modifications to archaeological sites. Notwithstanding this, implicit in the legislation is a dichotomy of scientific archaeological values, on the one hand, and Maori cultural or spiritual values on the other. This undoubtedly reflects the historical backgrounds of the archaeological fraternity and Maori communities over the past century. A question can be asked, though, about whether such a clear-cut separation will persist into the future and, indeed, is it always quite so clear cut now? This paper explores this question through a case study of the reuse of southern Maori rock-art imagery and the recent tribal management of two rock-shelter sites in the Waitaki Valley, South Island.

\section{Rock art is located in place}

Generally ... it is meaningless to isolate paintings and engravings from their natural settings. They are not individual works on the walls of cliffs or on rocks, like paintings hanging on the walls of a museum. Their full meaning can only be appreciated in a broader context, in which water, cliffs, shelters, rocks, and weather - and the sacred stories attached to them - are every bit as significant as the images created by men and women (Clottes 2002:60).

Modern rock-art research places a great deal of emphasis on the placement of the art in important and permanent venues. This applies at the macro level of sites in the wider landscape, as well as at the micro level of images within a panel - where they are positioned in relation to different images and other parts of the site (Chippindale and Nash 2004:1). As the choice on where to position rock-art figures was determined by the world view of the artists, the meaning of rock art generally derives from an aggregate of factors, including religious practices, natural landscape formations and weather, which results, for example, in rock art in many arid regions of the world being linked to the presence of water (Clottes 2002:58). Drawing on studies of Hawaiian petroglyphs in relation to boundaries, trails and places of ritual, Lee (2002) argues that the place and marking of place is as important as the petroglyphs themselves, and that even though the exact meaning of motifs might not be determined, their relevance to the creators and users of them can be. Within individual sites, accumulations of rock art in some places and not in others show how the position of existing images influenced the placement of later figures. There are several clear examples of this in North Otago shelters, where deliberate but avoidable superimpositions appear to have made careful connections to pre-existing rock-art figures (O’Regan 2007). Such accumulations may result from a psychological response of one drawing leading to another, such as seen in graffiti, or it may be sanctification, a phenomenon in which an initial painting invests the rock wall with power that subsequent artistic additions look to benefit from and add to (Clottes 2002:73). In either case, the setting, the physical character of the rock surface and the presence of other art all contribute to how a rock-art figure is placed and shaped.

South Island Maori rock art has been explained as 'time-filling scribbles of storm-stayed travellers' (Duff 1950:7) and the results of a pleasurable pastime incidental to sheltering in rock shelters during hunting expeditions (Trotter and McCulloch 1981:81). On the other hand, Fomison concluded that the positioning of some art in uninhabitable places indicated the artists went to those places with a purposeful intent of drawing (Trotter and McCulloch 1981:16). Schoon (1947:6-7) described the rock-art figures as 'products of a dream life ... [that] arise out of a religious concept which centred around a spirit-bearing world' and posited they reflected a positive function of artist-priests in the labyrinths of the South Island's limestone valleys. Whatever the case, common to all these explanations of the presence, purpose or meanings of 
southern Maori rock art, is some appreciation of the position of the art on the landscape.

There is a question as to what extent European contact-period rock art was a continuation of an earlier South Island tradition that dated to the time of moa hunting (see Trotter and McCulloch (1981:13, 81) and Anderson (1988) for contrasting views). Regardless, at the time of European contact, South Island Maori clearly knew of places in which rock art had been produced, and added to those places with images of European people, sailing ships and script in the Maori language. The process of Western colonisation shattered much of the traditional Maori world view within which the rock art had been created, and severed many of the relationships southern Maori communities had with the landscapes on which the art was positioned (O'Regan 2003). An appreciation of rock art in the landscape was not, then, something most Ngai Tahu throughout the 20th century would have experienced. If they encountered rock art at all, it would have most likely been in the form of images lifted from the landscape.

\section{A shift in place}

The first art to be graphically lifted from the landscape was images from the Takiroa site (NZAA SRS I40/9 in the New Zealand Archaeological Association Site Record Scheme) near Duntroon in the Waitaki Valley. Mantell's (1868:6-7) publication of a selection of paintings puts southern Maori rock art among the first aspects of the New Zealand archaeological record to have been formally recorded. While conducting a small archaeological excavation at Takiroa, Augustus Hamilton (1896) also photographed a number of the rock-art images there, as well as at the nearby Maerewhenua shelter (NZAA SRS I40/18). These glass-plate negatives survive in the Museum of New Zealand Te Papa Tongarewa photographic collection and provide a record of the figures before several were physically lifted from the sites for museum collections in about 1913 (Stevenson 1947:22). So it was that southern Maori rock art entered the New Zealand archaeological record. Its value as a resource for archaeological enquiry has been the focus of the attention it has received since.

It was in this light that from 1958 to 1960 , archaeologists set about recording rock-art sites further up the Waitaki Valley before their flooding for the Benmore hydro-generation scheme (Ambrose 1970:384). Various shelters were excavated and the rock art was recorded in detail, including an image from Shepherd's Creek that is now widely interpreted as a juvenile kiwi in an egg or, more colloquially, 'the kiwi embryo'. The site had long been known to local farm residents and was recorded by Stevenson (1947:32-33), who described the setting and other rock-art figures there but made no mention of the kiwi embryo. The published archaeological reports (Ambrose and Davis 1958; Ambrose 1970) do present the image and discuss its spatial context (Figure 1). As it appeared the figure was painted by a person leaning down from a ledge, the earlier report suggested the figure should probably be examined upside down, and presented it as such (Ambrose and Davis 1958:17). The later report presented the figure the other way up (Ambrose 1970:428). It also noted that the survival of the kiwi embryo painting in an exposed place may

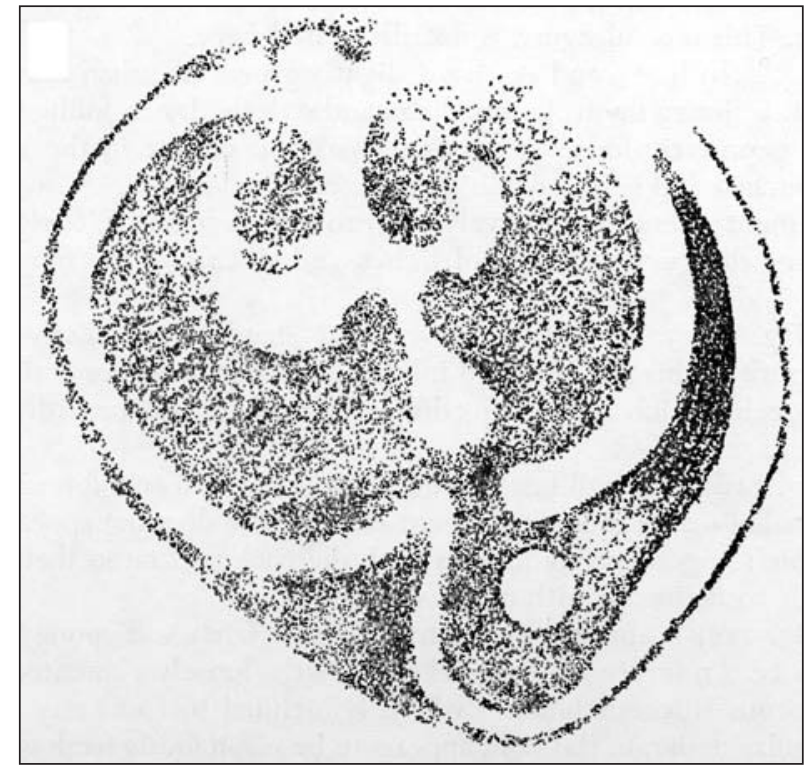

Figure 1. Archaeological recording of the kiwi-embryo rock-art figure by Wal Ambrose. In Records of the Canterbury Museum (1970) 8(5):428, Fig 22b (courtesy of the Canterbury Museum). 
indicate its recent age relative to more sheltered rock-art figures that were more weathered (Ambrose 1970:429). The landscape, the figure's position within it, and the relationship of the kiwi embryo image to surrounding rock art were all, then, a fundamental part of the archaeological interpretation. The same is not so, however, for the subsequent reuse of the imagery drawn from the archaeological record.

A notable reuse of the kiwi-embryo image within archaeological circles is its reproduction as the cover emblem for the New Zealand Journal of Archaeology, produced by the New Zealand Archaeological Association. There, the image has been given defined edges and vertically flipped, making it more obviously an avian form than is readily apparent in Ambrose's 1970 reproduction. A gap in the outer rim of the motif has also been filled, completing the 'egg shell'. There is no accompanying imagery, nor note that indicates the image is rock art.

Brian Allingham (pers comm. 2007) recalls seeing a reference by Duff to an inaccurate rendition of a rock-art image in a South Island newspaper, possibly the kiwi-embryo motif. While such an article has not yet been identified by the author, it may explain a version of the motif that found its way, among other rock-art images, on to a series of peanut-butter jars (Figure 2). Although upside down and distorted, with the addition of a protruding lug, the image is undoubtedly based on the Shepherd's Creek rock-art figure. Anecdotal accounts suggest the empty jars became drinking vessels in many New Zealand homes, commonplace before mass plastic packaging. Surviving examples are valued by some as 'kiwiana'.

The image is similarly found as an emblem on the crockery at Rehua Marae in Christchurch, where the lugged version inspired artwork in the whare (meeting house) Te Whatu-Manawa Maoritanga o Rehua that opened in 1960 (Figure 3). When building the whare, the marae elders wanted to include a specifically South Island pattern and, following a visit to the Waitaki Valley, adopted the kiwi-embryo image (Terry Ryan pers comm. 2006). An entwined pair of the motif was used to create a 'Unique Ngai Tahu design showing the embryonic kiwi' (Tau

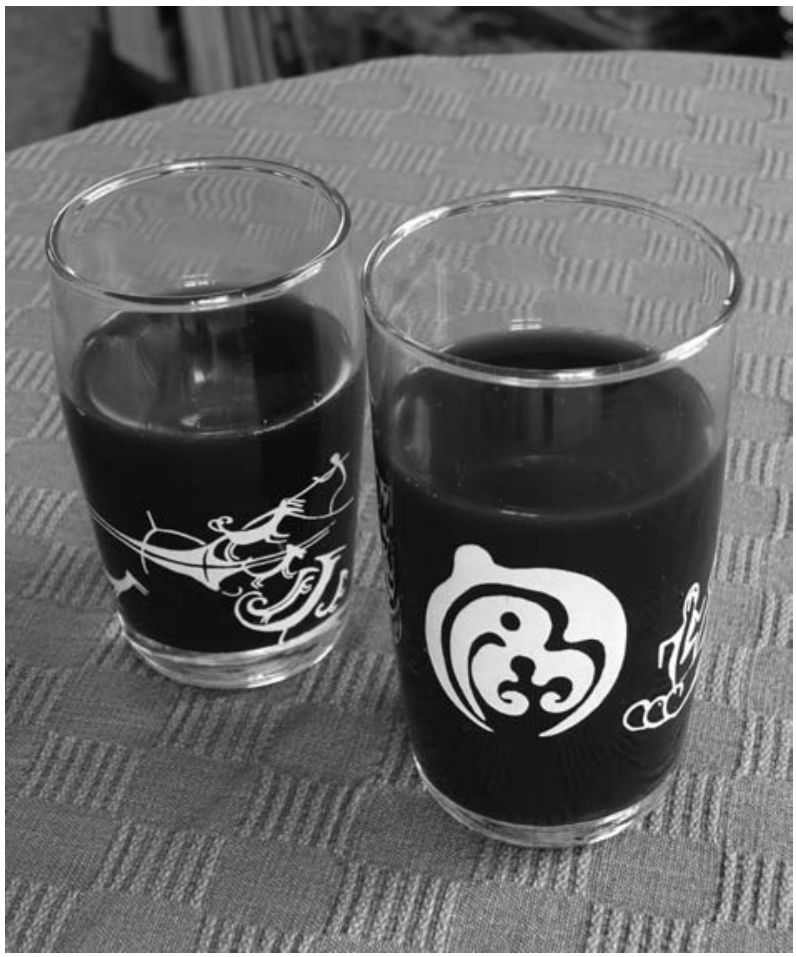

Figure 2. Rock-art images featured on a collector series of peanutbutter jars, now valued as examples of 'kiwiana'. et al. 1992:s5:81) for some of the rafters in a very traditional Maori context and among other very traditional Maori kowhaiwhai (rafter paintings), carvings and tukutuku (woven panels) (Figure 4). That pattern was subsequently further stylised for similar use in the meeting house Aoraki at the Nga Hau e Wha national marae, also in Christchurch. Whereas these meeting houses are very traditional Maori spaces, the placement of multiple images on the inside of whare is far removed from the original rock-shelter context of the motif. Further, both houses are located some distance from Shepherd's Creek and numerous other rock-art images can be found closer to hand. The kiwi-embryo motif is again included in a contemporary mural on the wall of the whare Uenuku, North Otago. Te Runanga o Moeraki, the Maori community there, considers itself the guardian of the area in which the kiwi embryo was recorded and its use in that instance is as a marker of local identity. It is depicted on a rock, albeit a Moeraki boulder, which is another heritage icon of the area, found on the local beach. 


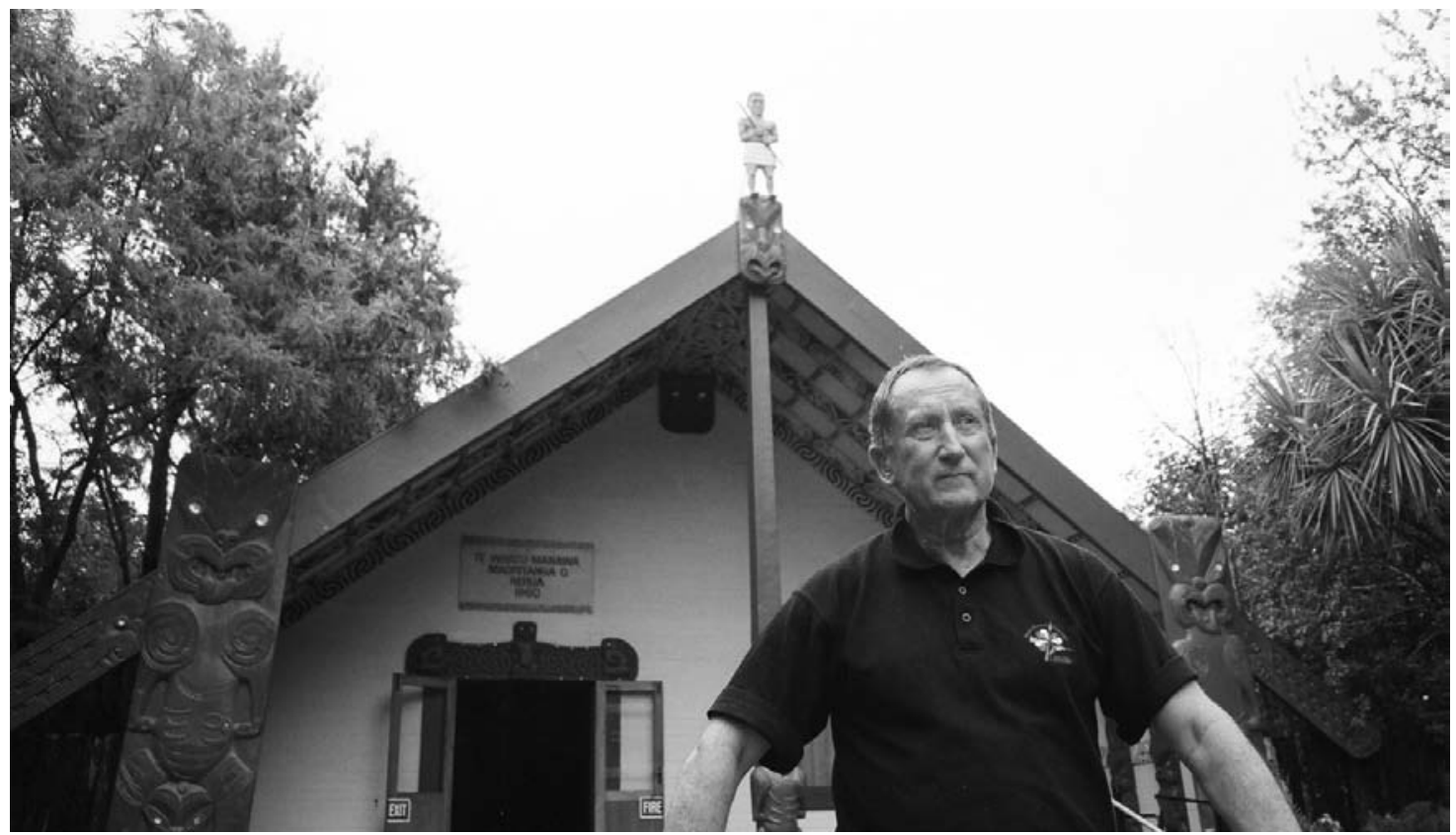

Figure 3. Terry Ryan recalls that in the late 1950s the elders of Rehua Marae wanted to include a uniquely southern Maori image in the meeting house, Te Whatu-Manawa Maoritanga o Rehua, that was being built (photo with permission of Rehua Marae).

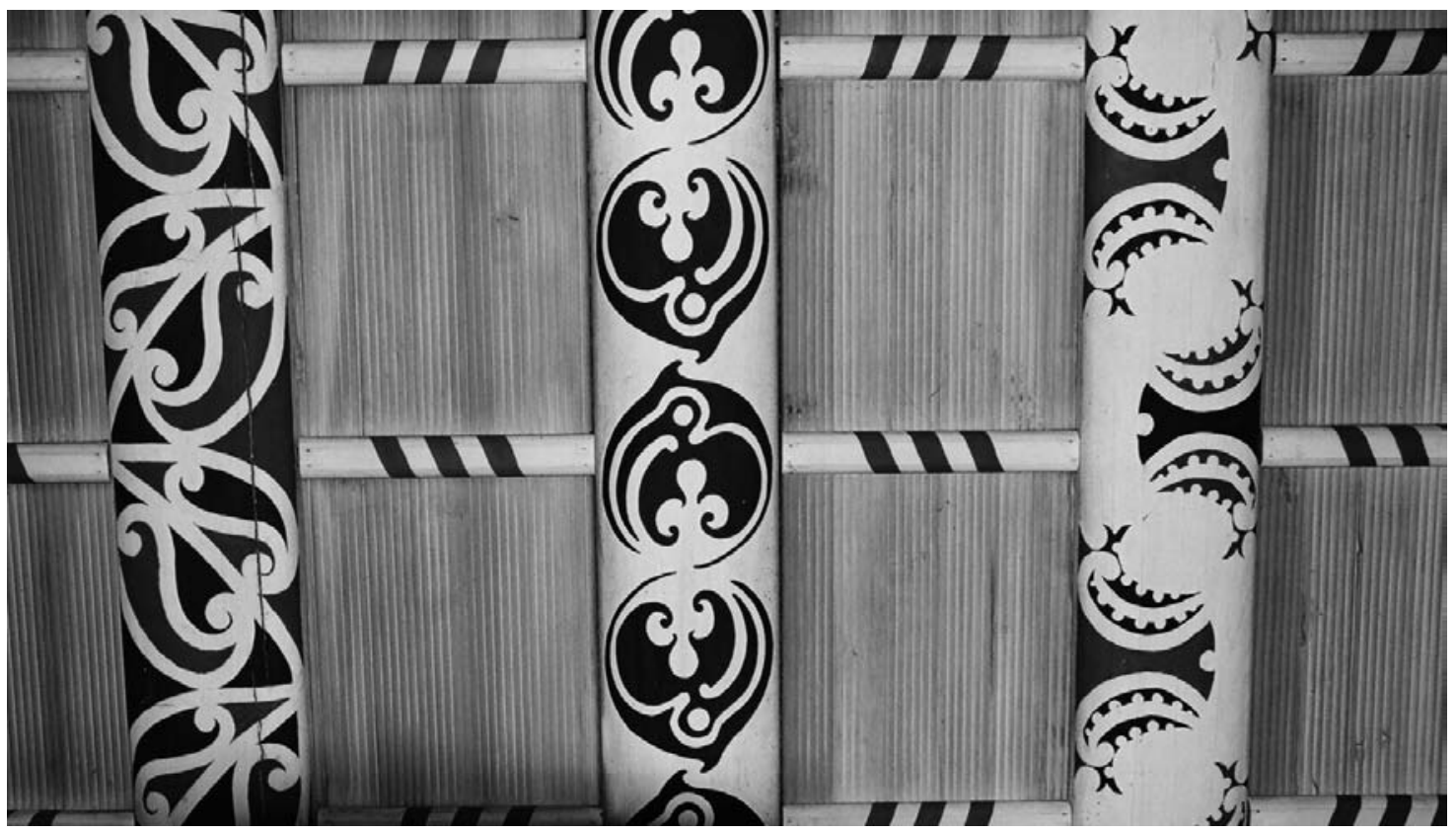

Figure 4. A unique Ngai Tahu design showing the embryonic kiwi, incorporated into the rafters of the meeting house (photo with permission of Rehua Marae).

The association of the motif with local identity is perhaps epitomised in its adaptation for a contemporary arts program commissioned by the tribal authority, Te Runanga o Ngai Tahu, in 2005. 'Pepeha in the City' was an initiative that sought to bring traditional Maori sayings to the fore in the Christchurch community. Artworks were commissioned and reproduced on cards distributed at community events. One of the artworks coupled several images of the kiwiembryo figure with the traditional saying 'ka pakihi whakatekateka a waitaha [sic], the plains where waitaha [sic] strutted proudly' (Figure 5). This is a specific reference to the Canterbury plains and not associated with the locality at Shepherd's Creek in the Waitaki Valley. 


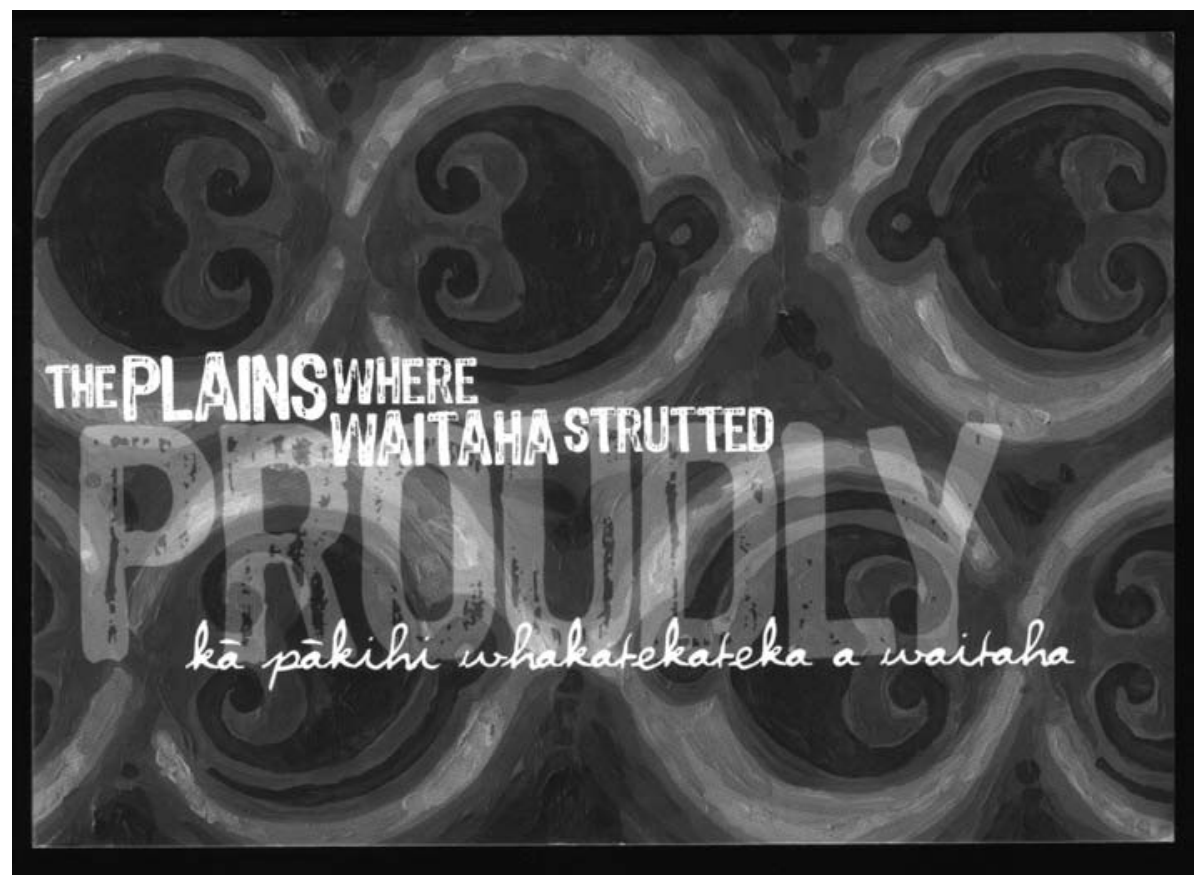

Figure 5. A card celebrating a southern Maori proverb associated with the Canterbury Plains. Designed by Frances Bryant (reproduced with permission of Te Runanga o Ngai Tahu).

The motif, as presented in the whare Rehua, was replicated as the corporate logo for the Ngai Tahu administration's Whakapapa Unit, which manages the genealogical records and registrations of the tribe. Terry Ryan (pers comm. 2006), the former manager of the unit explains its adoption as a symbol of reproduction and new growth. He points to others who shared that interpretation, such as Dunedin's Arai Te Uru cultural performance group, which incorporated it into the pari (bodices) of their performance costumes. Such use indicates that if there was a tapu (religious restriction) associated with the original placement of the art on the landscape, that was not perceived as a hindrance to wearing the motif on the body in the 1960s and 1970s.

Tribal discussions on rock art and other taonga (cultural treasures), such as the 2005 Ngai Tahu cultural symposium held at Huirapa, Karitane, quickly turn to concerns about the nontribal abuse of tribal intellectual and cultural property. The commercial exploitation of rockart designs, including reproductions on T-shirts for sale, is considered a misappropriation of cultural imagery and widely looked upon with disdain within the tribe. Recently, the Ngai Tahu Maori Rock Art Trust proposed producing a series of T-shirts, one of which incorporated the kiwi embryo, as a fundraiser. The local marae communities that maintain tribal authority over the rock-art images permitted the use, as sales were to be restricted to tribal members. Although permission was later granted for public sales, to increase returns for the protection of rock art, the marae's initial position reflected the idea that only tribal members should proudly wear the works of the ancestors. This expression of tribal pride exhibited through the rock-art imagery has extended to its incorporation in body art in the current ta moko (tattooing) renaissance. Among its other reuses, the kiwi embryo is permanently inked into the arms of the Kamo family of Canterbury (Figure 6).

This brief survey of the reuse of the kiwi-embryo image is far from comprehensive. Nor is the morphing of the images - from rock art on the landscape, to archaeological records, commercial misappropriation, kiwiana, meeting houses, contemporary artworks, corporate logos, group emblems and tattoos on the bodies of young Ngai Tahu - a unique story. The 


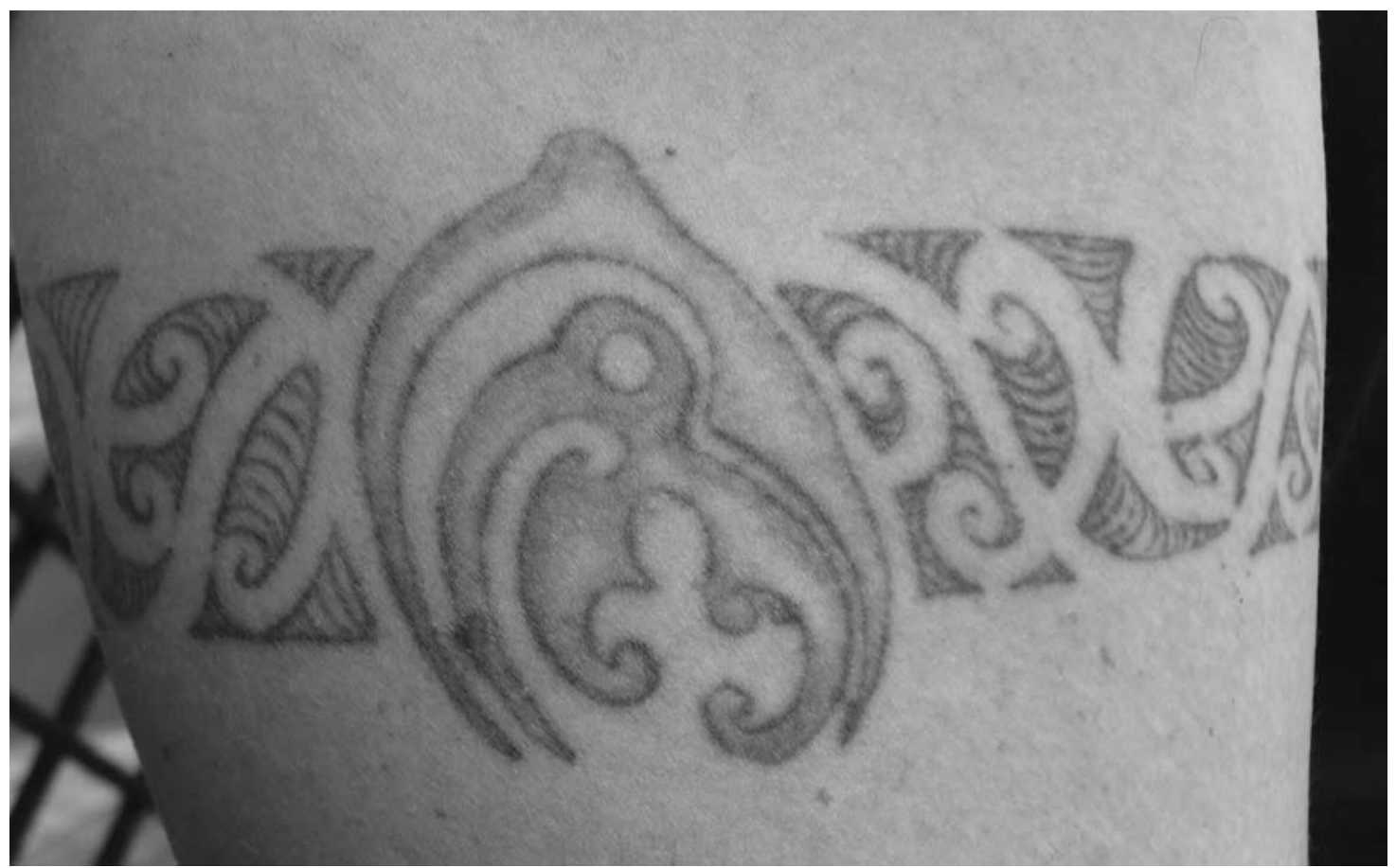

Figure 6. Ward Kamo shares the kiwi-embryo motif as a ta moko with his siblings. The design both connects them to their tribal landscape and celebrates their whanau (family) time at Rehua Marae.

same tale can be told about the eagle images from Te Manunui (Frenchmans Gully, NZAA SRS J39/17) and the renowned Opihi (NZAA SRS J38/75) taniwha images. Indeed, there are hundreds of examples of the modern use of southern Maori rock-art imagery. Each case reflects how the art has intrigued and inspired different people and groups, and how they have sought, albeit in their own ways, to celebrate it. The point of this review is to illustrate that the place of the kiwi-embryo image in Ngai Tahu culture has shifted, from rock art, on the one hand, to body art on the other. That is to say, it has undergone a transition from an artwork fixed in place in a landscape full of meaning, to what is at one extreme a taonga (treasure) ingrained in a person wherever in the world the person happens to be.

There are a number of factors to note in this transition. First, of the approximately 40,000 Ngai Tahu people today, none has seen the now flooded kiwi embryo image, and relatively few have seen other rock-art images in a landscape context. Second, it follows that as an appreciation of the location of the art in the landscape is fundamental to explanations of its meaning, purpose or presence, then these are largely lost in the reuse of the images, which are the limit of most people's experience of the art. Third, whereas Ngai Tahu generally disapproves of the use by others of tribal rock-art imagery in personal clothing, corporate logos, contemporary art and souvenir pieces, these are all things the tribe does itself, and sometimes for a wider market. This suggests the tribal position is less about what is being done, and more a question of who is doing it, and under whose mana (authority). These factors lead to a recognition of the new place of southern Maori rock art as a tribal heritage art form promoted as a statement of tribal identity. A relationship to a landscape is implicit in this, but it is to a wider rohe (tribal area), rather than to a specific rock shelter.

\section{Treasured sites}

Tracking the reuse of the rock-art imagery and its place in the modern tribe is interesting in terms of contemporary tribal arts and statements of identity. It is also of interest in understanding 
the rationale behind Ngai Tahu's management of some archaeological sites, including the aforementioned Takiroa and Maerewhenua rock-art shelters.

On the side of State Highway 83 and with at least 35,000 visitors a year, Takiroa is perhaps the most accessible and highly visited rock-art site in the country. The rock art extends along an interconnected series of shelters that undercut a large limestone bluff. Despite the removal of some figures for museum collections, the subsequent erosion and the ongoing weathering of the art, a large number of figures are still clearly visible, including some particularly large, bold, red paintings. The shelters were set aside as a historic reserve in 1981. An initial fence protected the main concentration of surviving figures. Further art is located beyond the area originally fenced and beyond the boundary of the reserve, which extends only a few metres in front of the main painted part of the shelter wall. In the mid 1990s, the Historic Places Trust developed a management plan for the site, which resulted in more extensive fencing covering more of the rock-art images, interpretive guide boards and a paved access route. The path crosses private farmland that has been actively grazed, resulting in the regular fouling of the path by cattle.

Four kilometres southeast of Takiroa, the Maerewhenua shelter is in the upper levels of a large limestone outcrop at the juncture of the Waitaki and Maerewhenua River valleys. From a side road a few hundred metres off State Highway 83, access to the shelter was by way of a stile over a farm fence and then up what can be described as a steep 'goat track' that climbed across private farmland directly to the shelter front. Despite a protective wire cage across the front of the shelter, the rock art concentrated on the rear wall is still readily visible to visitors. The historic reserve boundaries put in place in 1980 extend only as far as the shelter itself.

Both sites have archaeological evidence dating from the time of moa hunting. At the foot of the talus slope in front of the Maerewhenua shelter, Hamilton (1896:173) noted many moa bones, some of which were fragmented and cut. Allingham (nd) recorded moa bone from a small oven feature in front of the Takiroa shelter, and during his excavation at the site, Hamilton (1896:172-173) found a moa feather among the other avian remains above the 'Maori level', which contained lumps of kokowai (red iron oxide), which was used, among other purposes, for painting rock art. The character of the deposits found at both sites suggests they were used for short visits, rather than long-term occupation. There are only limited ethnohistorical references to southern Maori rock art, and none that explain the meaning of the art at Takiroa and Maerewhenua, nor why it was put there.

As historic reserves, both sites were managed by the New Zealand Historic Places Trust, mostly through its North Otago Branch Committee. As a result of the increase in interest in rock art following the tribe's 1993 adoption of the South Island Maori Rock Art Project survey, Te Runanga o Moeraki moved to increase tribal authority over the Takiroa site (O'Regan 1994). This eventually came about with the transfer of the management of the Maerewhenua and Takiroa sites to the tribe as part of cultural redress in the 1998 settlement of Ngai Tahu's historic land claim to the Waitangi Tribunal. The management is vested in the tribal council, Te Runanga o Ngai Tahu, with the local management responsibility being delegated to Te Runanga o Moeraki. Takiroa and Maerewhenua are the only two rock-art sites in North Otago managed directly by the tribe. Whereas Te Runanga o Moeraki supported the Historic Places Trust's previous efforts to improve visitor facilities at Takiroa, it remained dissatisfied with the state of presentation of the flagship sites. Accordingly, with the support of the Ngai Tahu Maori Rock Art Trust, it embarked on a site upgrade for each.

With the support of the landowners, the areas in front of the shelters were set aside and fenced from stock. Palisade-style fencing was erected, along with posts reminiscent of pou whenua (landmark posts) that carried new interpretation panels. These present more impressive 
entrances to the sites and extend the perceived spaces visited outwards from the shelter walls (Figure 7). At Maerewhenua, a properly stepped path of limestone chips in keeping with the natural environment now zigzags up the slope and eases the climb. The tired and patched caging was replaced and the path from which the art is viewed was levelled. Native species were planted at both sites, and will, with time, further distinguish the sites from the farmland. Following these upgrades, Transit New Zealand has arranged the purchase of neighbouring land to build a safe car-parking area for visitors to Takiroa. An on-site event marked the completion of the redevelopments in December 2007 (Figure 8). The two sites previously presented as caged shelters of archaeological interest in the middle of farm paddocks have been transformed into cared-for places that are distinctly recognisable as being of cultural significance to Maori.

\section{Conclusions}

The site developments at Takiroa and Maerewhenua have been warmly applauded in the community. There is little doubt the rock-art visitor experience at both sites is now more accessible, and enhanced with a stronger sense of 'old-time Maori'. Yet, how 'authentic' is the message imparted? The modern paths, particularly the steep frontal approach at Maerewhenua, may not reflect the way the artists accessed the sites (O'Regan 2007:138-139). Nor is there anything to suggest these sites ever had palisades, gateways or pou whenua. In themselves, the upgrades have done little to advance understanding of the meaning of the rock art or to directly contribute to its better conservation. Instead, the upgrades reflect the current place of rock art within Ngai Tahu culture as an expression of pride in the past, rather than a reiteration of that past. The efforts have been focused squarely on reflecting the rock art as something treasured. Emerging from this is the suggestion that the rationale behind the tribal reclamation of the management of the Takiroa and Maerewhenua sites and the recent upgrades is a concern for showing that the places are treasured and who is doing the treasuring, rather than a concern

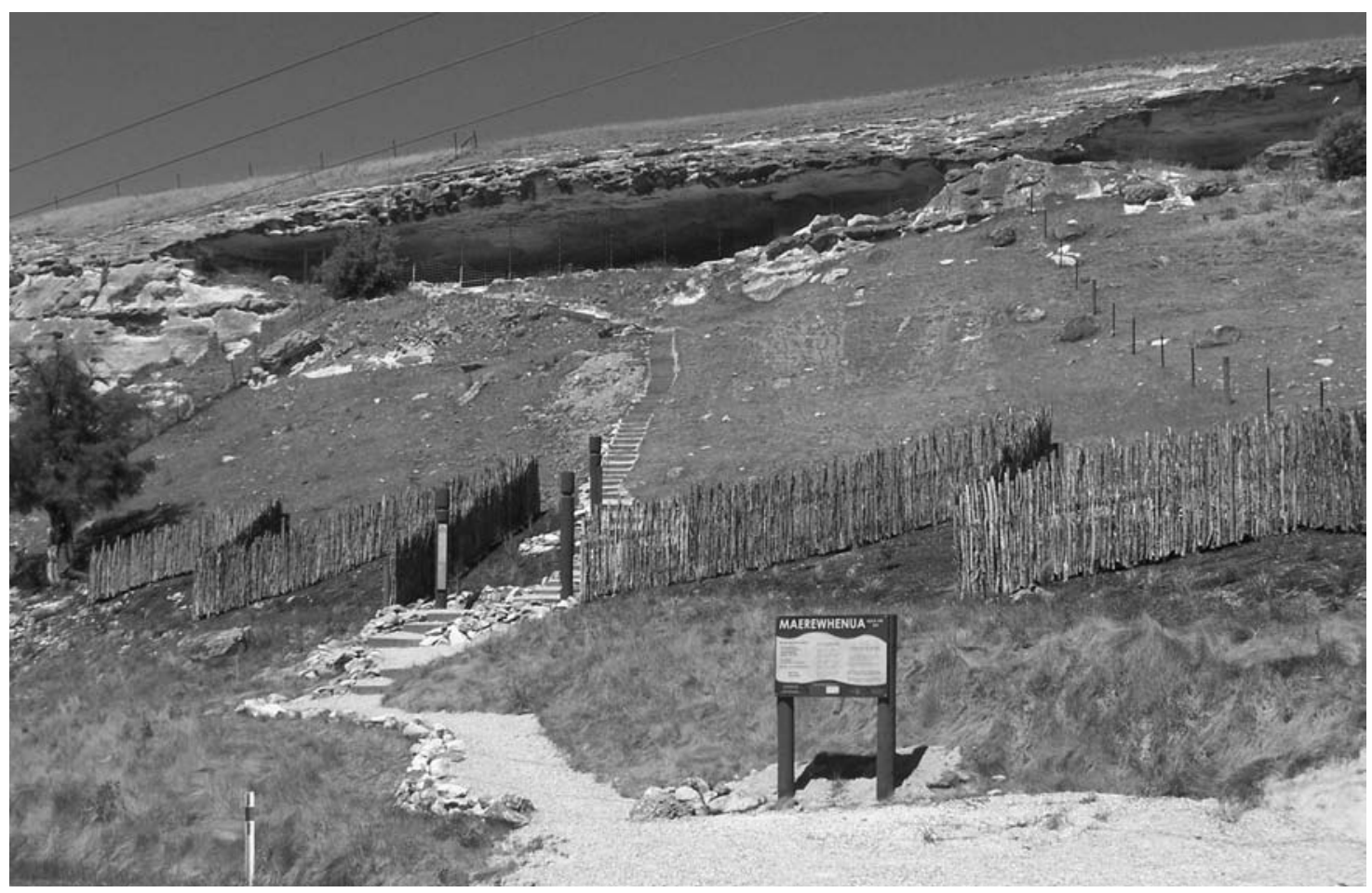

Figure 7. Along with the palisade-style fencing, native planting will increasingly shift the perspective of Maerewhenua away from being a caged archaeological site in the middle of a farm paddock (courtesy of Ellen Andersen). 


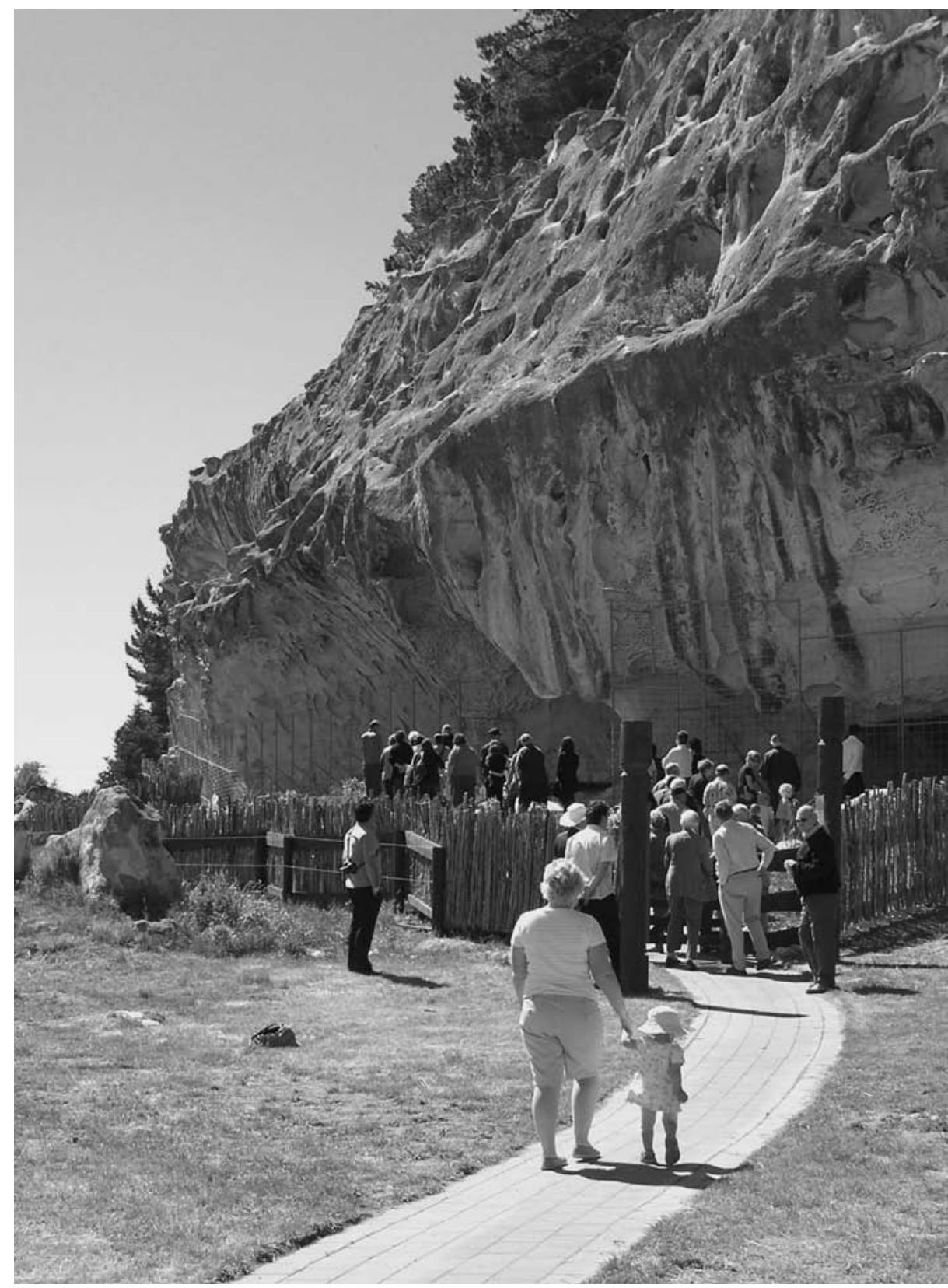

Figure 8. The local Maori community, Te Runanga o Moeraki, share its pride in the Takiroa rock art-site with other community members at the launch of the new visitor facilities, December 2007 (courtesy of Ellen Andersen).

for the presentation of archaeological or historical 'truths'. This is perhaps the fundamental difference in New Zealand between managing a place as an 'archaeological site' and managing it as a 'wahi tapu'.

Such developments are not unique to rock-art sites. The same phenomenon is demonstrated by the carved gateway at Huriawa pa site at Karitane, the interpretations and pou (posts) at Otatara Pa in Hawke's Bay, and numerous other places throughout New Zealand where pou whenua (posts that mark significant localities) have been set in place. Unlike pa sites, though, that often have detailed and significant tribal histories for which wahi tapu values can be easily recognised, at Takiroa and Maerewhenua it is the rock art itself, the archaeology of the site, that underpins the treatment of the places as wahi tapu. In these two cases, the distinction between 
the archaeological values and the wahi tapu values are blurred. The case also demonstrates that the archaeology of the sites is dynamic, with the story still unfolding.

As it stands today, southern Maori record wahi tapu, and some of these places may have archaeological values (Kai Tahu ki Otago 2005:63). Archaeologists record archaeological sites, but note they may have other values to Maori (Walton 1999:10). While the current legislative environment implies archaeological values are distinct from the Maori cultural values that underpin recognition of a place as a wahi tapu, the above discussion suggests that in regard to rock art at least, such a distinction is more perceived than actual. This blurring of values can be graphically tracked through the shifting place of rock art in Ngai Tahu culture. As we track the resultant shift in the modern management of rock-art sites, at least in so far as his own tribe's heritage is concerned, we can see the hand of Atholl Anderson from the outset.

\section{References}

Allingham, B. pers comm. Telephone discussion regarding the kiwi embryo motif, December 2007. Allingham, B. nd. Takiroa, Waitaki Valley, South Island Maori Rock Art Project Te Kaupapa i nga Tuhituhi Tawhito o Te Wai Pounamu, Vol. 4, unpublished report, Te Runanga o Ngai Tahu, Christchurch.

Ambrose, W. 1970. Archaeology and rock drawings from the Waitaki Gorge, Central South Island. Records of the Canterbury Museum 8(5):383-437.

Ambrose, W. and F. Davis 1958. Interim report on the recording of Maori rock shelter art at Benmore. Report of the National Historic Places Trust for the year ended 31 March 1958, pp. 11-23. Wellington: Government Printer.

Anderson, A. 1988. The art of concealment: Some thoughts on South Island Maori rock drawings. National Museum of New Zealand Te Whare Taonga o Aotearoa and Manawatu Art Gallery, $\mathrm{Ka}$ Tuhituhi o Nehera, The Drawings of Ancient Times. National Museum of New Zealand Te Whare Taonga o Aotearoa and Manawatu Art Gallery.

Chippindale, C. and G. Nash 2004. Pictures in place: Approaches to the figured landscapes of rockart. In C. Chippindale and G. Nash (eds), Pictures in Place: The Figured Landscapes of Rock-Art, pp.1-36. Cambridge: Cambridge University Press.

Clottes, J. 2002. World Rock Art. Los Angeles: The Getty Conservation Institute.

Duff, R. 1950. Maori art in rock drawings. Arts Year Book 6:6-11.

Hamilton, A. 1896. On some paintings on the walls of rock-shelters in the Waitaki Valley. Transactions and Proceedings of the New Zealand Institute 29:169-174.

Kai Tahu ki Otago 2005. Kai Tahu ki Otago Natural Resource Management Plan 2005. Dunedin: Kai Tahu ki Otago Ltd.

Lee, G. 2002. Wahi Pana: Legendary places on Hawai’i Island. In B. David and M. Wilson (eds), Inscribed Landscapes: Marking and Making Place, pp. 79-92. Honolulu: University of Hawai' i Press.

Mantell, W. 1868. Abstract of address on the Moa. Transactions and Proceedings of the New Zealand Institute 1:5-7.

Mead, H.M. 2003. Tikanga Maori: Living by Maori Values. Wellington: Huia Publishers.

New Zealand Historic Places Trust 2004. Heritage Management Guidelines for Resource Management Practitioners. Wellington: New Zealand Historic Places Trust.

O’Regan, G. 1994. Caring for rock art. New Zealand Historic Places 50:27-28.

O'Regan, G. 2003. The history and future of New Zealand Maori Rock Art - A Tribal Perspective. Before Farming: The archaeology and anthropology of hunter-gatherers 2003/1(9), viewed 1 August 2007, <http://www.waspress.co.uk>. 
O’Regan, G. 2006. Regaining Authority: Setting the agenda in Maori Heritage through the control and shaping of data. Public History Review 13:95-107.

O’Regan, G. 2007. Wahi tapu and rock art: an intra-site analysis of two Southern Maori rock art shelters. Unpublished MA thesis, Department of Anthropology, University of Auckland.

Ryan, T. pers comm. Email regarding the reuse of the kiwi embryo image, April 2006.

Schoon, T. 1947. New Zealand's oldest art galleries. New Zealand Listener, September 12:6-7.

Stevenson, G.B. 1947. Maori and Pakeha in North Otago. Wellington: A.H. and A.W. Reed.

Tau, Te M., A. Goodall, D. Palmer and R. Tau 1992. Te Whakatau Kaupapa: Ngai Tahu Resource Management Strategy for the Canterbury Region. Wellington: Aoraki Press.

Trotter, M. and B. McCulloch 1981. Prehistoric Rock Art of New Zealand. Auckland: Longman Paul Ltd.

Walton, T. 1999. Accessing the archaeological values of historic places: procedures, methods and field techniques. Science and Research Internal Report 167, Department of Conservation, Wellington. 